\title{
İş Aile Çatışması ve Çalışmaya Tutkunluk Arasındaki İlişkiye Yönelik
}

\section{Bir Araștırma}

\section{A Study on the Relationship between Work-Family Conflict and Work Engagement}

\author{
Doç. Dr. Mutlu TOKMAK (iD) 1
}

\begin{abstract}
$\ddot{\mathbf{O z}}$
$\mathrm{Bu}$ çalışmanın amacı, işgörenlerin yaşadıkları iş aile çatışması ile çalışmaya olan tutkunlukları arasındaki ilişkiyi ortaya koymaktır. Araştırma Türkiye'de Ağrı ilinde çalışan kamu kurumu personeline uygulanmıştır. Araştırmaya 170 kamu personeli katılmıştır. İş aile çatışması ve çalışmaya tutkunluk arasındaki ilişkinin belirlenmesi amacıyla korelâsyon analizi gerçekleştirilmiştir. Ayrıca iş aile çatışmasının çalı̧̧maya tutkunluk üzerindeki etkisini belirlemeye yönelik basit regresyon analizi gerçekleştirilmiştir. Korelâsyon analizi neticesinde istatistiksel olarak anlamlı sonuçlar elde edilmiş ancak regresyon analizi istatistiksel olarak ( $\mathrm{F}=3.833 ; \mathrm{R} 2=0.022 ; \mathrm{p}>0.05)$ anlamlı sonuç vermemiştir. Araştırma sonucunda, iş aile çatıșması ile çalıșmaya tutkunluk arasında negatif yönlü $(r=-0.201, p<0.01)$ ve anlamlı bir ilișki bulunmuştur. İş aile çatışması ile çalışmaya tutkunluk alt boyutlarından dinçlik ile negatif yönlü $(r=-0.326$, $\mathrm{p}<0.01)$, adanmışlık ile negatif yönlü $(\mathrm{r}=-0.193, \mathrm{p}<0.05)$ bir ilişki tespit edilmiştir. Çalışanların iş ve aile iliş̧ilerinde yaşadıkları olumsuzluklar, çalışma yaşamlarına negatif olarak yansımakta ve onların çalışmaya tutkunluklarını azaltmaktadır.
\end{abstract}

Anahtar Kelimeler: İş aile çatışması, çalışmaya tutkunluk, kamu çalışanları

Makale Türü: Araştırma

\begin{abstract}
The purpose of this study is to reveal the relationship between the work engagement and job family conflict that employees live. Research was applied to a provincial government agency working staff in Ağr1 province in Turkey. 170 public personnel participated in the study. Correlation analysis was performed to determine the relationship between work family conflict and working passion. In addition, simple regression analysis was carried out to determine the effect of work-family conflict on working engagement. As a result of the correlation analysis, statistically significant results were obtained, but regression analysis did not yield $(\mathrm{F}=3.833 ; \mathrm{R} 2=0.022 ; \mathrm{P}>0.05)$ statistically significant results. As a result of the research, a negative and significant relationship of $(\mathrm{r}=-0.201, \mathrm{p}<0.01)$ was found between work-family conflict and working engagement. Among the sub-dimensions of affection to work with work-family conflict, a relationship with vigour was negatively $(\mathrm{r}=-0.326, \mathrm{p}<0.01)$, and dedication and $(\mathrm{r}=-0.193, \mathrm{p}<0.05)$. The negativities experienced by the employees in their business and family relations reflect negatively on their working lives and reduce their passion for working.
\end{abstract}

Keywords: Work family conflict, working engagement, public employees

Paper Type: Research

${ }^{1}$ Jandarma ve Sahil Güvenlik Akademisi, Jandarma ve Sahil Güvenlik Fakültesi, mutlu-tokmak@hotmail.com.

Atıf için (to cite): Tokmak, M. (2021). İş aile çatışması ve çalışmaya tutkunluk arasındaki ilişkiye yönelik bir araştırma. Afyon Kocatepe Üniversitesi Sosyal Bilimler Dergisi, 23(1), 113-124. 


\section{Giriş}

Çalışma ortamları ile aile yaşamları uyumlu olan işgörenlerin çalışma yaşamlarında daha başarılı olabilecekleri açıktır. Bazı durumlarda çalışanların iş yaşamlarında karşılaştıkları sorunlar aile yaşamlarını da olumsuz etkilemektedir. Çalışanların iş ve aile yaşamlarında ki dengeyi kuramamaları ve çatışma halinde olmaları, iş yaşamlarında da kendilerini tam anlamıyla işlerine vermelerine engel olabilmektedir.

Bu çalışmada, işgörenlerin iş aile çatışma düzeyleri ile çalışmaya tutkunlukları arasındaki ilişki ortaya konmaya çalışılmaktadır. Bu amaçla, kamuda güvenlik görevini yerine getiren personel üzerinde alan araştırması gerçekleştirilmiş ve sonuçları literatürde yer alan bilgilerle karşılaştırmalı olarak aktarılmaya çalışılmıştır. Çalışmanın ilk bölümünde iş aile çatışması ve çalışmaya tutkunluk konularında ilgili yazında yer alan bilgilere yer verilmiştir. İkinci bölümde ise, araştırmanın yöntemi, kapsamı ve elde edilen verilerin analizine yer verilmiştir. Sonuç ve değerlendirme kısmında ise, elde edilen analiz bilgileri diğer araştırmalarla karşılaştırmalı olarak değerlendirilmiştir.

\section{Kavramsal Çerçeve}

İş aile çatışması ve çalışmaya tutkunluk kavramları bu bölümde açıklanmaya çalışılmaktadır. Ayrıca iş aile çatışması ve çatışmaya tutkunluk konularında literatürde yer alan araştırmalara da yer verilecektir.

\section{1 İş-Aile Çatışması Kavramı}

İnsanların hayatları boyunca yerine getirmeleri gereken birtakım roller bulunmaktadır ve bu rollerin yerine getirilmesi için mücadele hayat boyu devam etmektedir. Çalışma yaşamının başlamasıyla birlikte roller artmakta, hem iş yaşamında hem de iş dışındaki yaşama ilişkin roller arasında dengenin korunması gerekmektedir. Bu dengenin sağlanamaması durumunda iş aile çatışması ortaya çıkmaktadır (Korkmazer, 2018, s. 21).

İş ve aile çoğu insanlar için hayatın en önemli iki alanıdır. Eğer iş ve aile alanları arasında seçim yapmak zorunda kalınır ise bireyler genellikle ailelerini işlerinden daha önemli olduğunu belirtmektedirler (Gutek, Searle ve Klepa, 1991, s. 560). Aile ve iş ile ilgili rollerin bireye vermiş olduğu yükümlülüklerin her zaman kusursuz olarak ve sinerji içerisinde yerine getirilmesi her zaman mümkün değildir. Aile ve iş kapsamına ilişkin rol taleplerinin birbirleriyle uyumlu olmaması iki boyut arasında çatışmaların meydana gelmesine sebebiyet vermektedir. Bireylerin aile ve iş rollerinden kaynaklanan sorumluluklarını yerine getirebilmeleri için gereken en önemli kaynak zamandır. Bireyler aile ve iş alanı sorumluluklarının bilincinde olmalarına rağmen bu yükümlülüklerini gerçekleştirebilmeleri için gerekli zamana sahip olmadıklarından veya evde yaşadıkları stres iş performanslarını olumsuz etkilemekte, bundan dolayı iş-aile çatışması meydana gelmektedir (Kopelman, Greenhaus ve Connolly, 1983, s. 200).

İş-aile çatışması kavramı, iş veya aile alanlarında ortaya çıkacak genellikle birbiriyle ilişki içerisinde olmayan baskı ve olayların bireyler üzerinde oluşturduğu olumsuzluk durumu olarak açıklanmaktadır. Bu olumsuzluk, kişilerin bulunacağı herhangi bir alanda (iş, aile) meydana gelmesi halinde yer alacağı diğer alana da (iş, aile) yansıyarak ek olarak olumsuzluk meydana getirmektedir. Dolayısıyla hem iş hem de aile ortamlarında kişilerin içerisinde kalacağı olumsuz durumlar her iki ortamda da uyumsuzluklar doğurmakta ve sonucunda bireylerde çatışma durumu ortaya çıkmaktadır (Pitt-Catsouphes, Kossek ve Sweet, 2007, s. 76; Parasuraman ve Simmers, 2001, s. 556; Shakhbazov, 2018, s. 3). Literatürde, iş aile çatışmasının beklentilerin karşılanmadığ 1 durumlarda ortaya çıktığı görüşü hâkimdir (Greenhaus ve Beutell 1985, s. 76-88; Kinnunen ve Mauno, 1998, s. 158; Lambert, Hogan ve Barton, 2002, s. 36)

İş aile çatışmasının bireysel, ailesel ve örgütsel bazı sonuçları olmaktadır. Bu sonuçları şu şekilde açıklamak mümkündür (Gina ve Frone, 2005, s. 127-129; Açıkgöz, 2014, s. 61; Korkmazer, 2018, s. 51): 
Bireysel Sonuçlar: Kişinin genel olarak sağlı̆̆ının bozulması, strese bağlı olarak depresyon ve anksiyete durumunun ortaya çıkmasıdır. Bu olumsuz durumlar karşısında bireylerde sigara ve alkol tüketiminde artışlar görülmektedir.

Ailesel Sonuçlar: Kişinin ailesel rollerini gerçekleştirememesine bağlı olarak eşlerde artan ebeveyn yükü ve yaşamdan duyulan mutluluk seviyesinin azalmasıdır. Bu durumlara bağlı olarak kişinin aile yaşamında sorunlar ortaya çıkabilmektedir.

Örgütsel Sonuçlar: Kişinin iş yaşamında mutsuz olması ve buna bağlı olarak iş yerindeki performansının düşmesi şeklinde ortaya çıkmaktadır. Kişinin örgüte karşı bağ $l_{11} \breve{g ̆}_{1}$ azalmakta ve buna bağlı olarak işten ayrılma niyetinde artış görülmektedir.

\section{2 Çalışmaya Tutkunluk Kavramı}

Çalışmaya tutkunluk, kişinin işine bağlı olmasının ötesinde, tüm benliği ile kendini işe vermesi ve işten duyulan tatmin düzeyinin en üst seviyelere çıkmasını ifade etmektedir (Esen, 2011, s. 381). Çalışmaya tutkunluk kavramı ilk olarak Schaufeli, Salanova, Gonzalez-Roma ve Bakker (2002, s. 80) tarafından ortaya atılmıştır. Schaufeli vd. (2002, s. 80)' ne göre çalışmaya tutkunluk; olumlu, tatminkar, işine kendini adama ve işini benimse ile değerlendirilen ruh halidir. Koyuncu, Burke ve Fiksenbaum (2006, s. 300) 'a göre çalı̧̧maya tutkunluk duygusal-bilişsel boyutları da olan kısa bir süreliğine gelip geçici bir şekilde değil geniş bir zamanda görülen süreklilik gösteren bir durumdur. Poon (2013, s. 1149)'a göre ise çalışmaya tutkunluk, çalışanların kendilerini mutlu, sağlıklı görmelerinin, kendilerini iyi hissetmelerinin ve huzurlu olmalarının göstergesi şeklinde tanımlanmıştır. Çalışmaya tutkun çalışanlar örgütlerinin amaçlarına ulaşabilmesi için bireysel katılımda bulunmaktadır. Bireysel katılım; her bir bireyin örgüte katkıda bulunması anlamına gelmektedir (Kazan, 2008, s. 162).

Literatürde çalışmaya tutkunluğun; dinçlik, adanmışlık ve yoğunlaşma olmak üzere üç boyut ile ifade edildiği belirtilmektedir ve bu boyutlara ilişkin açıklamalar şu şekildedir (Güleryüz, 2016, s. 20-21; Turgut, 2011, s. 156):

Dinçlik Boyutu: Bu boyut çalışanın fiziksel olarak dayanıklılığını ifade etmektedir. İşgören diğer mesai arkadaşlarına naran daha az yorulur ve enerjisi diğerlerine göre daha fazladır. $\mathrm{Bu}$ boyutta kişi işi için harcadığı enerji konusunda son derece isteklidir ve işini ciddiye almaktadir.

Yoğunlaşma Boyutu: Bu boyutta kişinin işine karşı olan konsantrasyonunun en üst seviyede olduğu ve kişinin işine mutlulukla daldığı ifade edilmektedir.

Adanmışlık Boyutu: Bu boyutta çalışmaya karşı güçlü bir bağlılık vardır. Çalışanlar yaptıkları işle gurur duyarlar ve bir amaca hizmet ettiklerinin farkındadırlar. Yaptıkları çalışmayı hevesle yapmaktadırlar.

Kurumların çalışmaya tutkun çalışanlara sahip olabilmeleri için yapmaları gerekenler kısaca şu şekilde açıklanmaktadır (Çankır, 2016, s. 26; Hodgetts, 1997, ss. 451-452) :

i. İdareciler, çalışanlar arasındaki sadakatin az olduğunun farkında olmak zorundadır. $\mathrm{Bu}$ problem genellikle üst yönetim tarafından yetersiz işbirliği ortamı olmasından ve iletişim eksikliğinden dolayı bilinememektedir.

ii. İdareciler, örgütün vizyonunu çalışanlarla nasıl paylaşacaklarını öğrenmek zorundadır.

iii. Çalışan, örgütün çabalarında yer almalıdır. Planların bir parçası olduğunu ve örgütün kendisine güvendiğini hissetmek zorundadır.

iv. Yöneticiler, çalışanlara önemli görevler vererek ve bu görevlerin örgüt için kritik işler olduğunu belirterek çalışanların örgüte bağlılığını sağlamalarıdır.

v. Kurum, çalışanlarından girişimci ve sadık olanları maddi imkânlarla ödüllendirmelidir. Kademe arttıkça maddi ödül de artmalıdır. 
vi. Örgüt, kişilere tanınma olană̆ı ve diğer maddi olmayan ödüller vermelidir. İnsanlar iyi ve yaratıcı fikirlerinden dolayı övülmeli, daha fazla çalışmaları için cesaretlendirilmeli ve kendilerini işlerinde önemli bir birey olarak görülmelidir.

\subsection{Yazın Taraması ve Araştırmanın Hipotezleri}

İş aile çatışması üzerine yapılan araştırmalarda; uzun ve düzensiz çalışma saatleri (Baykal, 2014: 10), örgütün büyüklüğ̈ (Ahuja, Chudoba, Kacmar, McKnight ve George,2007, s. 1), üst yönetimin olumsuz tavrı ve iş ilişkileri (Parasuraman ve Simmers, 2001, s. 551), düşük ücret ve terfi (Frone, Yardley ve Markel 1997, s. 145), iş stresi (Kılıç ve Özafşarlıoğlu Sakallı, 2013, s.214), aile ilişkileri ve aile beklentileri (Cinamon, Weisel ve Tzuk, 2007, s. 79), sağlık durumu, çocuk sayısı, yaş, gelir, çalışan performansı (Madsen, 2003, s. 35) gibi çeşitli iş ve kişisel özellikler iş-aile çatışmasının en önemli nedenleri olarak görülmektedir. Cinsiyetin iş-aile çatışması üzerindeki etkisini inceleyen çalışmalarda da kadınların erkeklerden daha fazla çatışma yaşadıkları belirtilmektedir (Çelik ve Turunç, 2011, s. 230; Gutek vd., 1991, s. 560; Lo, 2003, s. 376). Yukarıdaki sebeplerin yanı sıra, sahip olunan çocuk sayısı, eşlerden her ikisinin de çalışması, eşlerin birbirlerine destek olmamaları, çocukların bakımı ve sorumluluklarının eşlerden birinde toplanması gibi nedenlerin de iş aile çatışmasına yol açtığ 1 ifade edilmektedir (Çelik ve Turunç, 2011, s. 230; Madsen, 2003, s. 35; Voydanoff, 1988, s. 749).

Çalışmaya tutkunluk ile ilgili yapılan çalışmalarda, çalışmaya tutkunluk düzeyi yüksek olan işgörenlerin diğer işgörenlere göre memnuniyet düzeylerinin daha fazla olduğu, kendilerini örgütlerine ait hissettikleri ve işten ayrılma düşüncelerinin daha düşük seviyelerde olduğu belirtilmiştir (Schaufeli ve Bakker, 2004, s. 293; Demerouti, Bakker, De Jonge, Jansse ve Schaufeli, 2001, s. 279). Bedenen ve zihnen çalışmaya tutkun işgörenlerin kendilerini daha iyi hissettikleri görülmüştür. Sorumluluk alma, öğrenme arzusu ve verimli davranışlar sergileme isteği çalışmaya tutkun personelde daha yüksektir (Sonnentag, 2003, s. 518; Çalışkan, 2014, s. 371).

Zöğ (2007, s. 15) tarafından eğitim çalışanları üzerine yapılan araştırmada, çalışmaya tutkunluk ile işgörenlerin iş doyumları arasında pozitif bir ilişsinin olduğu tespit edilmiştir. Karagöz (2008, s. 4) tarafından yapılan araştırmada da yöneticilerin etik liderlik rolleri ile işgörenlerin çalışmaya tutkunlukları arasında ilişki olduğu saptanmıştır.

İş aile çatışması ve çalışmaya tutkunluk arasındaki ilişkiyi inceleyen ulusal ve uluslararası çalışmalar yer almaktadır. Öge, Çetin ve Top (2018, s. 25) tarafından hava kontrolörlerine yönelik yapılan, çalışmaya tutkunluk ile iş aile çatışması arasındaki ilişkiyi ölçen araştırmaya göre, iş aile çatışmasının işgörenlerin çalışmaya tutkunluklarını olumsuz yönde etkilediği tespit edilmiştir. Karatepe ve Karadaş (2006, s. 560) tarafından Romanya'da otel çalışanlarına yönelik yapılan araştırmada, iş aile çatışması ile çalışmaya tutkunluk arasında negatif yönlü ve 0.408 oranında ilişki olduğu belirlenmiştir. Ayrıca, araştırmada gerçekleştirilen regresyon analizi neticesinde iş aile çatışmasının çalışmaya tutkunluğu negatif yönde 0.26 oranında etkilediği tespit edilmiştir. Opie ve Henn (2013, s. 6) tarafından çalışan annelere yönelik yapılan bir araştırmada, iş aile çatışması ve çalışmaya tutkunluk arasındaki ilişki incelenmiş ve iş aile çatışmasın ile çalışmaya tutkunluk arasında negatif yönlü ve 0.19 oranında ilişki olduğu sonucuna ulaşılmıştır. Rothmann ve Baumann (2014, s. 523) tarafından Namibya'da maden çalışanlarına yönelik gerçekleştirilen araştırmada, iş aile çatışması ve çalışmaya tutkunluk arasında negatif yönlü ve 0.16 oranında ilişki olduğu tespit edilmiştir. Turgut (2011, s. 168) tarafından yapılan benzer bir çalışmada iş aile çatışmasının çalışmaya tutkunluk boyutları ile ilişkisi araştırılmıştır. Zaman temelli iş aile çatışması ile çalışmaya tutkunluk boyutlarından dinçlik ile negatif yönlü 0.26 ve adanmışlık ile negatif yönlü 0.28 oranında ilişki içerisinde olduğu, duygu temelli iş aile çatışması ile dinçlik boyutunun negatif yönlü 0.31 ve adanmışlık boyutu ile negatif yönlü 0.44 oranında ilişki içerisinde olduğu belirlenmiştir. 
Literatürdeki araştırmalara katkı olarak, bu çalışmada da iş aile çatışması ve çalışmaya tutkunluk arasındaki ilişkinin yönü ve seviyesi araştırılmaktadır. Bu amaçla aşağıdaki hipotezler geliştirilmiş ve test edilmeye çalışılmıştır.

Hipotez 1: İş aile çatışması ile çalı̧̧maya tutkunluk arasında negatif yönlü bir ilişsi vardir.

Hipotez 2: Çalışmaya tutkunluk boyutlarından "Dinçlik" boyutu ile iş aile çatışması arasında negatif yönlü bir ilişki vardır.

Hipotez 3: Çalışmaya tutkunluk boyutlarından "Yoğunlaşma" boyutu ile iş aile çatışması arasında negatif yönlü bir ilişki vardır.

Hipotez 4: Çalışmaya tutkunluk boyutlarından "Adanmışlık” boyutu ile iş aile çatışması arasında negatif yönlü bir ilişki vardır.

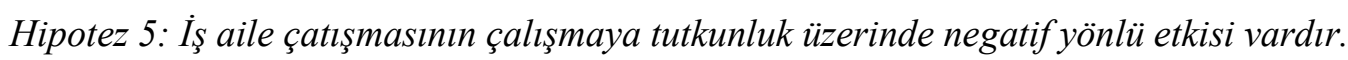

\section{Metodoloji}

$\mathrm{Bu}$ bölümde araştırmanın amacı, yöntemi, örneklemi ve veri toplama aracı hakkında bilgi verilecektir. Araştırma neticesinde toplanan verilerin değerlendirilmesi de bu kısımda yer almaktadır.

\subsection{Araştırmanın Amacı ve Yöntemi}

$\mathrm{Bu}$ çalışmada amaç, iş aile çatışması ile çalışmaya tutkunluk arasındaki ilişkiyi ortaya koymaktır. Ayrıca iş aile çatışmasının, çalışmaya tutkunluk boyutları olan dinçlik, yoğunlaşma ve adanmışlı boyutları ile olan ilişkileri de araştırılacaktır. Bu amaçla alan araştırılması gerçekleştirilmiştir. Alan araştırmasında anket yöntemi kullanılmıştır. İş aile çatışmasını ölçmek amacıyla Carlson (2000) tarafından geliştirilen soru formundan yararlanılmıştır. İşgörenlerin çalışmaya tutkunluk düzeylerini ölçmek için de Schaufeli vd. (2002) tarafından oluşturulan ölçekten yararlanılmıştır. Araştırmada geliştirilen hipotezlerin değerlendirilmesinde korelasyon analizi kullanılmıştır. Belirlenen hipotezlerin test edilmesi için korelâsyon analizinden yararlanılmıştır. Ayrıca katılımcıların görüşlerini tespit etmek amacıyla betimsel istatistik verilerine yer verilmiştir.

\subsection{Araştırmanın Örneklemi ve Veri Toplama Aracı}

Araştırma güvenlik hizmeti sunan kamu çalışanlarına yönelik gerçekleştirilmiştir. Araştırmada kolayda örnekleme yöntemi belirlenmiştir. Türkiye'de Ağrı ilinde güvenlik hizmeti veren kamu çalışanları örneklem olarak alınmıştır. Çalışanlara 200 anket formu dağıtılmış, 170 anketten geri dönüş sağlanabilmiştir. Araştırmanın bir ilde yapılmış olması nedeniyle genelleme yapma iddias1 yoktur.

Araştırma için veri toplama yöntemlerinden anket tekniği kullanılmıştır. Araştırmada kullanılan anket üç bölümden oluşmaktadır. İlk bölümde yaş, eğitim, gelir düzeyi vb. gibi demografik bilgilere yer verilmiştir. Anket formunun ikinci bölümünde iş aile çatışmasına yönelik bilgilerin toplandığ 1 ölçekten yararlanılmıştır. Üçüncü bölümde ise katılımcıların çalışmaya tutkunluk düzeylerini belirlemeye yönelik ölçek yer almaktadır.

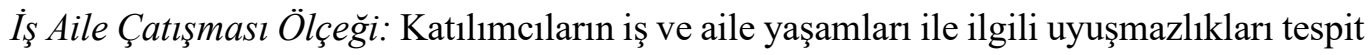
etmek amacıyla Carlson (2000) tarafından geliştirilen ve Erdoğan (2009) tarafından Türkçe uyarlaması gerçekleştirilen soru formu kullanılmıştır. Anket formunda iş aile çatışmasına yönelik altı ifade yer almaktadır. Ölçekte yer alan ifadelerde, 1-Kesinlikle Katılmıyorum, 5-Kesinlikle Katılıyorum şeklinde 5'li likert ölçeği kullanılmıştır.

Çalışmaya Tutkunluk Ölçeği: Araştırmaya katılan kamu güvenlik personelinin çalışmaya tutkunluğu yönelik tutumlarını tespit etmek amacıyla Schaufeli vd. (2002) tarafından geliştirilen ve Turgut (2011) tarafindan Türkçe' ye uyarlaması gerçekleştirilen soru formundan 
yararlanılmıştır. Ölçekte on yedi ifade yer almaktadır ve orijinal ölçekte dinçlik, yoğunlaşma ve adanmışlık olmak üzere üç boyutta değerlendirilmiştir. Ölçekte 5'li likert ölçeği kullanılmış olup 1-Kesinlikle Katılmiyorum, 5-Kesinlikle Kat1lıyorum' u ifade etmektedir.

\subsection{Araştırma Bulgularının Değerlendirilmesi}

Araştırma bulgularının değerlendirilmesinde IBM SPSS 22. 0 paket programı kullanılmıştır. Belirlenen hipotezler \%95 güven aralığında test edilmiştir. İş aile çatışması ve çalışmaya tutkunluk boyutları belirlenirken orijinal ölçekte yer alan ifadeler, ölçeğe bağlı kalarak gruplandırılmış ve boyutlara isimleri verilmiştir.

\subsubsection{Demografik Veriler}

Araştırmaya katılan kamu çalışanlarının demografik özellikleri Tablo 1'de gösterilmektedir.

Tablo1. Demografik özellikler

\begin{tabular}{|c|c|c|c|}
\hline Demografik Bilgiler & & Frekans & Yüzde (\%) \\
\hline \multirow{4}{*}{ Yaş } & 25 yaş ve altı & 66 & 38.8 \\
\hline & $26-31$ yaş aras1 & 77 & 45.3 \\
\hline & $32-37$ yaş aras1 & 19 & 11.2 \\
\hline & 38 Yaş ve üzeri & 8 & 4.7 \\
\hline \multirow{3}{*}{ Eğitim Durumu } & Lise & 83 & 48.8 \\
\hline & Önlisans & 66 & 38.8 \\
\hline & Lisans & 21 & 12.4 \\
\hline \multirow{2}{*}{ Medeni Durum } & Evli & 83 & 48.8 \\
\hline & Bekâr & 87 & 51,2 \\
\hline \multirow{5}{*}{ Gelir Durumu } & $4500-5000 \mathrm{TL}$ aras 1 & 27 & 15.9 \\
\hline & $5001-5500 \mathrm{TL}$ aras 1 & 89 & 52.4 \\
\hline & $5501-6000 \mathrm{TL}$ aras 1 & 15 & 8.8 \\
\hline & $6001-6500 \mathrm{TL}$ aras1 & 11 & 6.5 \\
\hline & $6501 \mathrm{TL}$ ve üzeri & 28 & 16.5 \\
\hline \multirow{4}{*}{ Mesleki Kıdem } & 1-4 Yil & 78 & 45.9 \\
\hline & 5-8 Yil & 72 & 42.4 \\
\hline & 9-12 Y11 & 15 & 8.8 \\
\hline & 13 yıl ve üzeri & 5 & 2.9 \\
\hline \multirow{6}{*}{ Kurumdaki Çalışma Yııı } & $1 Y_{11}$ & 11 & 6.5 \\
\hline & 2 Yil & 47 & 27.6 \\
\hline & 3 Yil & 43 & 25.3 \\
\hline & 4 Yil & 36 & 21.2 \\
\hline & 5 Yil ve Üzeri & 33 & 19.4 \\
\hline & TOPLAM & 170 & 100.0 \\
\hline
\end{tabular}

Tablo 1'e göre araştırmaya katılanların yarıya yakını 26-31 yaş aralığında yer almaktadır. Eğitim durumları incelendiğinde yaklaşık \%50'lik kısmı lise mezunudur. Medeni durumlarına bakıldığında yarıya yakın kısmının evli, diğer yarısının bekâr katılımcılardan oluştuğu görülmektedir. Gelir düzeyleri incelendiğinde yarıdan fazlasının 5001 ile 5500 TL arasında aylık gelire sahiptirler. Araştırmaya katılanların büyük çoğunluğunun mesleki kıdemleri 8 yılın 
altındadır. Araştırmaya katılanların şu anda bulundukları birimde çalışma yılında ise 2-3 yıl olanlar daha fazladır.

\subsubsection{Güvenilirlik Analizi ve Tanımlayıcı İstatistikler}

Araştırmada kullanılan ölçeğin güvenilirlik değeri (Cronbach’s Alpha) 0.949 çıkmıştır. Personelin çalışmaya tutkunluk düzeylerini belirlemek amacıyla kullanılan ölçeğin güvenilirliği ise (Cronbach's Alpha) 0. 933' tür. Güvenilirlik düzeyi $0.80 \leq \alpha \leq 1.00$ aralığında ise ölçek yüksek derecede güvenilir bir ölçektir (Kalayc1, 2008, s. 405). Her iki ölçeğin de güvenilirlik düzeyi oldukça yükssektir. Ölçeklere ilişkin ortalama ve standart hatalar Tablo 2'de gösterilmektedir.

Tablo 2. İş aile çatışması ölçeği tanımlayıcı istatistik sonuçları

\begin{tabular}{llllll}
\hline İş Aile Çatışması Ölçeği & N & Min. & Max. & Ort. & S.S. \\
\hline İş Aile Çatışması & 170 & 1.00 & 5.00 & 3.21 & 1.78 \\
\hline
\end{tabular}

İş aile çatışması ölçeği 6 ifadeden oluşmaktadır ve tek boyut olarak değerlendirmeye tabi tutulmuştur. Ölçeğe ilişkin betimsel istatistik verileri incelendiğinde iş aile çatışması ölçeği ortalamasının 3.21 olduğu görülmektedir. 5'li likert sisteminde ortalama değerin üç olduğu düşünüldüğünde, araştırmaya katılan kamu güvenlik çalışanlarının iş aile çatışması düzeylerinin ortalamanın üzerinde olduğu görülmektedir. Güvenlik hizmetlerinde çalışan kamu personelinin mesailerinin yoğun olması, uzun süreli güvenlik hizmeti sunmaları ve iş streslerinin yüksek oluşu iş aile çatışmasına neden olan başlıca etkenler olarak görülmektedir.

Çalışmaya tutkunluk ölçeğinde 17 ifade yer almaktadır. Schaufelli vd., (2002) tarafından geliştirilen orijinal ölçekte ifadeler üç boyutta gruplandırılmıştır. Araştırmada orijinal ölçekteki alt boyutlara sadık kalınarak dinçlik, yoğunlaşma ve adanmışlık olmak üzere üç alt boyut olarak değerlendirilmiştir.

Tablo 3. Çalışmaya tutkunluk ölçeği tanımlayıcı istatistik sonuçları

\begin{tabular}{llllll}
\hline Çalışmaya Tutkunluk Ölçeği & N & Min. & Max. & Ort. & S.S. \\
\hline Dinçlik & 170 & 1.00 & 5.00 & 3.48 & 0.91 \\
\hline Yoğunlaşma & 170 & 1.00 & 5.00 & 3.28 & 0.84 \\
\hline Adanmışlık & 170 & 1.00 & 5.00 & 3.95 & 1.00 \\
\hline Çalışmaya Tutkunluk Ölçeği (Genel Ortalama) & 170 & 1.00 & 5.00 & 3.55 & 0.79 \\
\hline
\end{tabular}

Araştırmaya katılan personelin çalışmaya tutkunluk düzeylerinin belirlenmesine yönelik tanımlayıcı istatistik sonuçlarının gösterildiği Tablo 3'e göre, çalışmaya tutkunluk düzeyinin genel ortalamasının 3.55 ile ortalama değerin biraz üstünde olduğu görülmektedir. Çalışmaya tutkunluk alt boyutlarından; dinçlik boyutunun 3.48; yoğunlaşma boyutunun 3.28; adanmışlık boyutunun ise 3.95 ortalamaya sahip olduğu belirlenmiştir. Çalışmaya tutkunluk boyutlarından adanmışl1k boyutu en yüksek ortalamaya sahiptir.

\subsubsection{Araștırma Hipotezlerinin Test Edilmesi}

Araştırmada belirlenen hipotezlerin sınanması için korelasyon analizinden yararlanılmıştır. Analiz sonucu elde edilen tablolar aşağıda yer almaktadır. 
Tablo 4. İş aile çatışması ve çalışmaya tutkunluk ilişkisi

\begin{tabular}{|c|c|c|c|c|c|}
\hline Korelâsyon & & 蛋急 & 誉 & 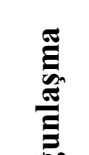 & 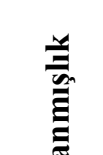 \\
\hline & $\begin{array}{l}\text { Korelâsyon } \\
\text { Katsayis1 } \\
\end{array}$ & $-.201^{* * *}$ & $-.326^{* *}$ & .042 & $-.193^{*}$ \\
\hline İş-Aile & $\begin{array}{l}\text { Sig. } \\
\text { (2-kuyruklu) }\end{array}$ & .009 & .000 & .589 & .011 \\
\hline & Kişi & 170 & 170 & 170 & 170 \\
\hline
\end{tabular}

$* \mathrm{p}<0,05 * * \mathrm{p}<0,01$ düzeyinde anlamlıdır. vardir.

Hipotez 1: İ̧s aile çatışması ile çalı̧̧maya tutkunluk arasında negatif yönlü bir ilişsi

Tablo 4'te görüldüğü üzere, kamu güvenlik çalışanlarının iş aile çatışması ile çalışmaya tutkunluk arasındaki ilişkiyi ve yönünü belirlemek için gerçekleştirilen korelâsyon analizi neticesinde negatif yönlü ve anlamlı $(\mathrm{r}=-0.201, \mathrm{p}<0.01)$ bir ilişki bulunmuştur. İş aile çatışması personelin çalışmaya tutkunluk düzeyini olumsuz yönde 0.201 oranında azaltmaktadır. Analiz neticesinde hipotez 1'in desteklendiği görülmektedir.

Hipotez 2: Çalışmaya tutkunluk boyutlarından "Dinçlik" boyutu ile iş aile çatışması arasında negatif yönlü bir ilişsi vardır.

Araştırmaya katılan kamu güvenlik personelinin, çalışmaya tutkunluk boyutlarından dinçlik boyutu ile iş aile çatışma durumları arasında negatif yönlü ve istatistiksel olarak anlamlı düzeyde $(\mathrm{r}=-0.326, \mathrm{p}<0.01)$ bir ilişki olduğu tespit edilmiştir. Tablo 4 'te görüldüğü üzere, iş aile çatışması çalışanların dinçlik tutumunu 0.326 oranında azaltmaktadır. Analiz neticesinde hipotez 2'nin desteklendiği görülmektedir.

Hipotez 3: Çalışmaya tutkunluk boyutlarından "Yoğunlaşma" boyutu ile iş aile çatışması arasında negatif yönlü bir ilişki vardır.

Tablo 4'te belirtildiği gibi, korelâsyon analizi neticesinde kamu güvenlik personelinin iş aile çatışması düzeyleri ile çalışma tutumu boyutlarından yoğunlaşma boyutu arasında istatistiksel olarak anlamlı derecede bir ilişki $(r=0.042, \mathrm{p}>0.01)$ olmadığ 1 tespit edilmiştir. Analiz neticesinde hipotez 3 'ün desteklenmediği görülmektedir.

Hipotez 4: Çalışmaya tutkunluk boyutlarından "Adanmışlık” boyutu ile iş aile çatışması arasında negatif yönlü bir iliş̧ki vardır.

Kamu güvenlik personeline yönelik yapılan araştırma sonucunda, çalışmaya tutkunluk boyutlarından adanmışlık boyutu ile iş aile çatışma durumları arasında negatif yönlü ve istatistiksel olarak anlamlı derecede $(\mathrm{r}=-0.193, \mathrm{p}<0.05)$ bir ilişki olduğu tespit edilmiştir. Tablo 4'e göre, iş aile çatışması çalışanların adanmışlık tutumunu 0. 193 oranında azaltmaktadır. Analiz neticesinde hipotez 4'ün desteklendiği görülmektedir.

\section{Hipotez 5: Işs aile çatışmasının çalışmaya tutkunluk üzerinde negatif yönlü etkisi vardır}

Araştırmaya katılan çalışanların iş aile çatışması düzeylerinin çalışmaya tutkunluk üzerindeki etkisini belirlemek için doğrusal regresyon analizi uygulanmıştır. 
Tablo 5. Basit doğrusal regresyon analizi

\begin{tabular}{l|c|c|c|c|c}
\hline Bağımlı Değişken: Çalışmaya Tutkunluk \\
\hline Bağımsız Değişken & $\mathbf{R}^{\mathbf{2}}$ & $\mathbf{F}$ & $\boldsymbol{\beta}$ & $\mathbf{t}$ & $\mathbf{p}$ \\
\hline İş Aile Çatışması & .022 & 3.833 & -.092 & -1.958 & .052 \\
\hline
\end{tabular}

Araştırmaya katılan kamu güvenlik personelinin iş aile çatışması düzeylerinin çalışmaya tutkunluk üzerindeki etkisine yönelik yapılan basit regresyon analizi neticesinde ( $\mathrm{F}=3.833$; $\mathrm{R} 2=0.022 ; \mathrm{p}>0.05)$ anlamlı sonuçlar elde edilememiştir. Basit doğrusal regresyon analizi neticesinde hipotez 5 desteklenmemektedir.

\section{Değerlendirme ve Sonuç}

İş aile çatışması, çalışanların iş yaşamı ile aile yaşamı arasındaki yaşanan olumsuzlukları ifade etmektedir. Ailede yaşanan olumsuzluklar işgörenlerin çalışma yaşamlarına da olumsuz etki edebilmektedir. $\mathrm{Bu}$ çalışmada, kamuda güvenliğini sağlamak amacıyla çalışan personelin yaşadıkları iş aile çatışması ile çalışmaya tutkunluk düzeyleri arasındaki ilişki araştırılmaktadır.

Kamu çalışanlarına yönelik yapılan araştırma sonucunda, personelin yaşadığı iş aile çatışmasının onların çalışmaya tutkunlukları ile negatif yönlü ilişki içerisinde olduğu tespit edilmiştir. Kamuda güvenliği sağlamak amacıyla çalışan personelin mesaileri çok uzun ve düzensiz olabilmektedir. Ayrıca iş yaşamlarında karşılaştıkları olaylar neticesinde stres düzeyleri yüksek bir görev icra etmektedirler. Bu durum ailelerine çok fazla zaman ayıramamalarına sebep olabilir. İçinde bulundukları iş aile çatışması, görevlerine olan tutkunluklarına da olumsuz düzeyde yansıyabilmektedir. Literatürde yapılan benzer araştırmalar neticesinde de, iş aile çatışmasının çalışmaya tutkunluk ile negatif yönlü ilişki içerisinde olduğu belirlenmiştir (Karatepe ve Karadaş, 2006, s.560; Opie ve Henn, 2013, s. 1; Rothman ve Bauman, 2014, s. 523; Turgut, 2011, s. 168).

Araştırma neticesinde, çalışmaya tutkunluk boyutlarından "işimi yaparken enerji dolu olurum", "işimde kendimi güçlü ve dinç hissederim", "sabah uyandığımda işe gitmek için istekli olurum", çok uzun saatler çalışabilirim" gibi ifadelerin yer aldığı dinçlik boyutu ile iş aile çatışması arasında negatif yönlü bir ilişki olduğu sonucuna ulaşılmıştır. Çalışamaya tutkunluk boyutlarından "çalışırken işime dalıp giderim", "çalışırken yaptığım işe kendimi kaptırırım", "yoğun çalıştığım zamanlarda kendimi mutlu hissederim" gibi ifadelerin yer aldığ yoğunlaşma boyutu ile iş aile çatışması arasında anlamlı düzeyde bir ilişkinin olmadığı görülmektedir. "Yaptığım işin anlamlı olduğunu ve bir amaca hizmet ettiğini düşünüyorum", "işimin ilgi çekici ve gayret gerektiren bir iş olduğunu düşünüyorum", "yaptığım işle gurur duyarım" gibi ifadelerin yer aldığ çalışmaya tutkunluk boyutlarından adanmışlık boyutunun da iş aile çatışması ile negatif yönlü ilişki içerisinde olduğu tespit edilmiştir. Turgut (2011, s. 168) tarafından hizmet sektörü çalışanlarına yönelik yapılan araştırmada, bu çalışma ile benzer sonuçlar elde edilmiş, iş aile çatışması ile çalışmaya tutkunluk boyutlarından dinçlik ve adanmışlık boyutları arasında negatif yönlü ilişki olduğu, yoğunluk boyutu ile iş aile çatışması arasında anlamlı bir ilişki olmadığı belirtilmiştir.

İş aile çatışmasının, işgörenlerin çalışmaya tutkunluklarına olan etkisini belirlemek amaciyla gerçekleştirilen regresyon analizi neticesinde istatistik olarak anlamlı bir sonuç elde edilememiştir. Rothman ve Bauman (2014, s. 523), Öge, Çetin ve Top (2018, s. 25) ve Opie ve Henn (2013, s. 6) tarafından yapılan benzer araştırmalarda iş aile çatışmasının personelin çalışmaya tutkunluğunu negatif yönde etkilediği tespit edilmiştir.

Sonuç olarak, çalışanların aile yaşamlarında karşılaştıkları olumsuz durumlar çalışmaya tutkunluklarını etkilemektedir. İşgörenlerin çalışmaya tutkunluk düzeylerini yükseltmek için iş 
aile çatışma düzeylerini en aza indirmek gerekmektedir. Yöneticilerin çalışanlardan üst düzeyde verimlilik elde edebilmeleri ve onların işlerine tutkuyla bağlı olmalarını sağlayabilmek için onları olumsuz etkileyen iş aile çatışmasının nedenlerini araştırıp bunları azaltıcı önlem almaları gerekmektedir.

Sonraki araştırmalara öneri olarak ise, iş aile çatışması ile çalışmaya tutkunluk arasındaki ilişkiyi değişik sektörlerde ve kamu-özel karşılaştırmalı olarak gerçekleştirmek literatüre katkı sağlayacaktır. Ayrıca iş aile çatışmasını en aza indirmek amacıyla yapılması gerekenler konusunda yönetici ve işgörenlerin görüşlerinin yer aldığı bir araştırma da hem akademik hem de iş dünyasına katkı sağlayacaktır.

\section{Kaynakça}

Açıkgöz, B. (2014). Çalışan annelerde başa çıkma stratejilerinin iş-aile çatı̧ması üzerindeki etkileri: Zonguldak örneği (Yayımlanmamış doktora tezi). Bülent Ecevit Üniversitesi Zonguldak.

Ahuja, M. K., Chudoba, K. M., Kacmar, C. J., McKnight, D. H. ve George, J. F. (2007). IT road warriors: Balancing work-family conflict, job autonomy, and Work Overload to Mitigate Turnover Intentions, MIS Quarterly, 31(1), 1-17.

Baykal, B. (2014). Çalışma saatleri iş-aile çatışması açısından belirleyici midir? Erkek çalışanlar açısından bir inceleme. Çalı̧̧ma İliş̧kileri Dergisi, 5(2), 10-23.

Carlson, D. S., Kacmar, K. M. ve Williams, L. J. (2000). Construction and initial validation of a multidimensional measure of work-family conflict. Journal of Vocational Behavior, 56(2), 249-276.

Cinamon, R. G., Weisel, A. ve Tzuk, K. (2007). Work-family conflict within the family: crossover effects, perceived parent-child interaction quality, parental self-efficacy, and life role attributions. Journal of Career Development, 34(1), 79-100.

Çalışkan, C.S. (2014), Pozitif örgütsel davranış değişkenleri ile yeni araştırma modelleri geliştirme arayışları: pozitif örgütsel davranış değişkenlerinin işe adanmışlık, tükenmişlik ve sinizm üzerine etkileri ve bu etkileşimde örgütsel adalet algısının aracılık rolü üzerine bir araştırma, Dokuz Eylül Üniversitesi SBE Dergisi, 16(3), 363-382.

Çankır, B. (2016). Çalışmaya tutkunluk ve tükenmişliğin örgütsel vatandaşlık davranışı üzerinde etkisi ve bir uygulama (Yayımlanmamış doktora tezi). İstanbul Üniversitesi, İstanbul.

Çelik, M. ve Turunç, Ö. (2011). Duygusal emek ve psikolojik sıkıntı: İ̧̧-aile çatışmasının aracılık etkisi, İstanbul Üniversitesi Işletme Fakültesi Dergisi, 40 (2), 226-250.

Demerouti, E., Bakker, A. B., De Jonge, J., Janssen, P. P. ve Schaufeli, W. B. (2001). Burnout and engagement at work as function of demands and control, Scandinavian Journal of Work Environment and Health, 27 (4), 279-286.

Erdoğan, I. (2009). The relationship between work-family conflict, life role salience and individual coping styles: A gender-sensitive study (Yayımlanmamış yüksek lisans tezi). Marmara Üniversitesi, İstanbul.

Esen, E. (2011). Çalışanların örgüte cezbolması, Marmara Üniversitesi İIBF Dergisi, 30(1), 377 390.

Frone, M. R., Yardley, J. K. ve Markel, K. S. (1997). Developing and testing an integrative model of the work-family interface. Journal of Vocational Behavior, 50(2), 145-167.

Gina M. B. ve Frone, M. K. (2005); Chapter 6: Work-family conflict, handbook of work stress, (Ed.: J. Barling, E. K. Kelloway ve M. R. Frone), California: Sage Publications. 
Greenhaus, J. H. ve Beutell, N. J. (1985). Sources of conflict between work and family roles. Academy of Management Review, 10(1), 76-88.

Gutek, B. A., Searle, S. ve Klepa, L. (1991). Rational versus gender role explanations for workfamily conflict. Journal of Applied Psychology, 76(4), 560-568.

Güleryüz, İ. (2016). Öğretmenlerde işten ayrılma niyetinin yordayıcısı olarak, iş-yaşam dengesi ve çalışmaya tutkunluk (Yayımlanmamış yüksek lisans tezi). Bahçeşehir Üniversitesi, İstanbul.

Hodgetts, R. M. (1997). Yönetim: Teori, süreç ve uygulama, (Çev. Çetin, C. ve Mutlu, E. C.), İstanbul Der Yayınevi.

Kalaycı, Ş., (2008). SPSS uygulamalı çok değişkenli istatistik teknikleri. (3.Baskı), Ankara: Asil Yayın Dağıtım.

Karagöz, A. (2008) Illk ve ortaögrretim okulu yöneticilerinin öğretmenler tarafindan algllanan etik liderlik rolleri ile ögretmenlerin örgütsel adanmışlıkları arasındaki iliş̧ki (Yayımlanmamış yüksek lisans tezi). Yeditepe Üniversitesi, İstanbul.

Karatepe, O. M. ve Karadas, G. (2016). Service employees' fit, work-family conflict, and work engagement, Journal of Services Marketing, 30(5), 554-566.

Kazan, H. ve Ergülen, A. (2008). Toplam kalite yönetimi araç ve tekniklerinin üretimde etkin k1lınmas1: Kobi uygulaması. Süleyman Demirel Üniversitesi İktisadi ve İdari Bilimler Fakültesi Dergisi, 13(1), 159-182.

Kılıç, R. ve Özafşarlığlu Sakallı, S. (2013). Örgütlerde stres kaynaklarının çalışanların iş-aile çatışması üzerine etkisi. Uşak Üniversitesi Sosyal Bilimler Dergisi, 6(3), 208-237.

Kinnunen, U. ve Mauno, S. (1998). Antecedents and outcomes of work-family conflict among employed women and men in Finland. Human Relations, 51(2), 157-177.

Kopelman, R. E., Greenhaus, J. H. ve Connolly, T. F. (1983). A model of work, family and interrole conflict: A construct validation study. Organizational Behavior and Human Performance, 32(2), 198-215.

Korkmazer, F. (2018), Işs yükü fazlalı̆̆ algısının yaşam kalitesi üzerindeki etkisi: iş- aile çatışmasının aracı rolü, (Yayımlanmamış doktora tezi). İnönü Üniversitesi, Malatya.

Koyuncu, M., Burke, R. J. ve Fiksenbaum, L. (2006) Work engagement among women managers and professionals in a Turkish bank: Potential antecedents and consequences. Equal Opportunities International, 25(4), 299-310.

Lambert, E. G., Hogan, N. L. ve Barton, S. M. (2002). The impact of work-family conflict on correctional staff job satisfaction: An exploratory study. American Journal of Criminal Justice, 27(1), 35-52.

Lo, S. (2003). Perceptions of work-family conflict among married female professionals in Hong Kong. Personnel Review, 32(3), 376-390.

Madsen, S. R. (2003). The effects of home-based teleworking on work-family conflict, Human Resource Development Quarterly, 14(1), 35-58.

Opie, T. J. ve Henn, C. M. (2013). Work-family conflict and work engagement among mothers: Conscientiousness and neuroticism as moderators. SA Journal of Industrial Psychology, 39(1), $1-12$.

Öge, E., Cetin, M., \& Top, S. (2018). The effects of paternalistic leadership on workplace loneliness, work family conflict and work engagement among air traffic controllers in Turkey. Journal of Air Transport Management, 66, 25-35. 
Parasuraman, S. ve Simmers, C. A. (2001). Type of employment, work-family conflict and wellbeing: a comparative study. Journal of Organizational Behavior, 22(5), 551-568.

Pitt-Catsouphes, M., Kossek, E. ve Sweet, S. (2006). The work and family handbook. New York: Routledge.

Poon, J. M. (2013). Relationships among perceived career support, affective commitment and work engagement, International Journal of Psychology, 48(6), 1148-1155.

Rothmann, S. ve Baumann, C. (2014). Employee engagement: the effects of work-home/homework interaction and psychological conditions. South African Journal of Economic and Management Sciences, 17(4), 515-530.

Schaufeli, W. B. ve Bakker A. B. (2004). Job demands, job resources and their relationship with burnout and engagement: A multi-sample study, Journal of Organizational Behavior, 25 (3), 293-315.

Schaufeli, W.B., Salanova, M., Gonzalez-Roma, V. ve Bakker, A. B. (2002) The measurement of engagement and burnout: A confirmative analytic approach, Journal of Happiness Studies, 3, 71-92

Shakhbazov, A. (2018), İş-aile çatışmasının işten ayrılma niyeti ile ilişkisi: Bir alan araştırması (Yayımlanmamış yüksek lisans tezi). İstanbul Üniversitesi, İstanbul.

Sonnentag, S. (2003) Recovery, work engagement and proactive behavior: a new look at the interface between nonwork and work, Journal of Applied Psychology, 88 (3), 518-528.

Turgut, T. (2011). Çalışmaya tutkunluk: İş yükü, esnek çalışma saatleri, yönetici desteği ve işaile çatışması ile ilişkileri, Atatürk Üniversitesi İktisadi ve İdari Bilimler Dergisi, 25(3-4), 155 179.

Voydanoff, P. (1988). Work role characteristics, family structure demands, and work/family conflict. Journal of Marriage and the Family, 50(3), 749-761.

Zöğ, H. (2007) İstanbul ili Kă̆gthane ilçesinde görev yapan ilköğretim okulu öğretmenlerinin örgütsel adanmışlıkları ile iş doyumları arasındaki ilişki (Yayımlanmamış yüksek lisans tezi). Yıldız Teknik Üniversitesi, İstanbul.

ETIKK ve BİLIMSEL İLKELER SORUMLULUK BEYANI

$\mathrm{Bu}$ çalışmanın tüm hazırlanma süreçlerinde etik kurallara ve bilimsel atıf gösterme ilkelerine riayet edildiğini yazar(lar) beyan eder. Aksi bir durumun tespiti halinde Afyon Kocatepe Üniversitesi Sosyal Bilimler Dergisi'nin hiçbir sorumluluğu olmayıp, tüm sorumluluk makale yazarlarına aittir.

\section{ARAŞTIRMACILARIN MAKALEYE KATKI ORANI BEYANI}

1. yazar katk1 oranı: $\% 100$ 